\title{
Entrevista
}

\section{Entrevista com a Dra. Paola Sinibaldi da Universidade de Roma Tor Vergata}

\section{1-Qual foi a principal motivação para a realização da parceria do Projeto da Universidade Tor Vergata com a UERJ?}

Para nós, a UERJ, é uma Universidade que consideramos amiga; talvez tenha sido a primeira universidade brasileira a colaborar com a nossa Universidade de Tor Vergata. Começamos a trabalhar juntos há muitos anos; no início, na área de Letras, agora, também na área da Saúde. Consideramos a UERJ uma Universidade de alto nível e muito aberta às colaborações internacionais; por isso nos damos muito bem.

Gostei também muito da existência desta revista e gostei também de fazer esta entrevista. Todas as Universidades no mundo têm o papel de formar estudantes, mas eu acho muito importante, como neste caso, estender as informações a toda a comunidade.

\section{2-Quais são os objetivos para realização desta parceria com a UERJ/Brasil?}

Existem já muitos projetos entre as duas universidades, algum mais antigos outros mais recentes. No meu caso, este projeto que vai acontecer na Copa do Mundo, tem o objetivo de promover a saúde através da "atividade física" e "nutrição" utilizando apenas alimentos típicos brasileiros. Aproveitando a presença de uma multidão de turistas que vão chegar ao Brasil para o Campeonato, vamos tentar representar os produtos brasileiros saudáveis para que eles conheçam, comprem e levem para utilizar nas suas refeições no próprio país. 


\section{3-Quais são as metas a serem alcançadas com essa parceria e com o desenvolvimento das atividades do projeto?}

Como já citado antes, o objetivo deste projeto é promover a saúde através da atividade física e da nutrição. A atividade física regular, como já feita no Brasil, reduz o risco de morte prematura como no caso de doenças cardiovasculares, vários tipos de cânceres e outras doenças metabólicas como hipertensão, obesidade, diabete etc. Esta redução do risco de doenças é mais eficaz se acompanhada de uma alimentação saudável. Por isso gostaríamos de fazer uma revisão e uma reavaliação dos produtos típicos brasileiros, com a colaboração das áreas de Nutrição da Universidade de Tor
Vergata e da UERJ, e ao mesmo tempo divulgar todas estas informaçoes à população do Brasil e aos estrangeiros. O Brasil é um país cheio de riquezas naturais que não podemos esquecer ou deixar de falar nisso.

\section{4-Quais são os principais desafios encontrados para o desenvolvimento do Projeto?}

$\mathrm{Na}$ realidade tudo está correndo bem; talvez a distância seja o maior desafio, mas apesar disso eu pessoalmente tento comparecer o maior número de vezes possível ao Brasil para acompanhar o trabalho de perto. Estive no Brasil no mês de outubro e já estou programando uma outra viagem em fevereiro. 